\title{
Environment Management Reporting Disclosure Before And After Sustainability Development Goals
}

\author{
Lisna Lisnawati ${ }^{1}$, Yati Mulyati ${ }^{2}$ \\ ${ }^{1}$ STIE Sebelas April Sumedang \\ ${ }^{2}$ Universitas Widyatama Bandung, Fakultas Ekonomi dan Bisnis
}

\begin{abstract}
Abstrak
Penelitian ini menganalisis aspek Environment Management Reporting Disclosure pada sektor pulp and paper yang sudah tercatat di Bursa Indonesia sebagai bentuk tanggung jawab terhadap Manusia (people), Bumi (planet) and keuntungan (profit) pada triple bottom line sebagai bagian dari Sustainability Development Goals (SDGs). Penelitian ini bertujuan untuk melihat adakah kesamaan atau perbedaan antara pengungkapan sebelum dan sesudah SDGs. Metode yang digunakan dalam penelitian adalah menggunakan pendekatan analisis konten/isi kuantitatif (quantitave content analysis) terhadap konten website perusahaan pulp and paper dengan unit fisik, unit sintaksis dan unit tematik. Hasil penelitian dengan menggunakan uji beda untuk menganalisa apakah ada perbedaan pengungkapan konten di website sebelum dan sesudah SDGs adalah tidak ada perbedaan signifikan antara pengungkapan sebelum dan sesudah sustainability. Terdapat dua variabel konservasi hewan dan rating yang tidak di ungkapkan dalam laporan dan hanya $66 \%$ pengungkapan dilakukan secara konsisten setiap tahunnya oleh entitas. Implikasi penelitian adalah harus terdapat pedoman yang pasti dan rinci terkait dengan pengungkapan Environment Management Reporting sehingga terdapat keseragaman dalam mengungkapkan laporan lingkungan.
\end{abstract}

Kata Kunci: Analisis konten, Environmental Management Reporting, Triple Bottom Line

\begin{abstract}
This study analyzes the aspects of the Environment Management Reporting Disclosure in pulp and paper manufacturing companies listed on the Indonesia Stock Exchange as a form of responsibility for people, planet and profit in the triple bottom line as part of the Sustainability Development Goals (SDGs). The purpose of this study is to see whether there are similarities or differences between disclosures before and after the SDGs. This research method is to use a quantitative content analysis approach to the content of the pulp and paper company website with physical units, syntactic units and thematic units. The results of the study used different tests to analyze whether there was a difference in content disclosure on the website before and after the SDGs is the meaning that there was no significant difference between disclosure before and after sustainability. There are two variables of animal conservation and rating that are not disclosed in the report and only $66 \%$ of the disclosures are made consistently annually by the entity. The implication of this research is that there must be definite and detailed guidelines related to the disclosure of Environment Management Reporting so that there is uniformity in disclosing environmental reports.
\end{abstract}

Keywords: Content Analysis, Environmental Management Reporting, Triple Bottom Line 


\section{PENDAHULUAN}

Perubahan iklim dan berkurangnya paru-paru dunia yang ditandai dengan berkurangnya luas hutan di dunia yaitu 4,3 juta ha periode waktu 2014-2020 mengindikasikan kondisi yang semakin mendekati kritis karena perilaku manusia dalam memanfaatkan sumber daya alam. Indonesia dengan luas hutan mencapai $884.950 \mathrm{~km}^{2}$, berada di posisi ke-9 sebagai negara dengan hutan terluas di dunia. Namun semakin tahun semakin berkurang karena pembabatan hutan menjadi perkebunan sawit dan alih fungsi hutan lainya. Kondisi tersebut salah satu nya kerena pemanfaatan hasil hutan menjadi bahan dasar produk-produk industri.

Entitas sebagai bagian dari ekosistem pengguna hasil hutan harus bisa ikut bertanggung jawab dan memberikan solusi untuk mengembalikan fungsi hutan sebagai paru-paru dunia. Hal tersebut terimplementasi dalam peraturan perundang-undangan yang berlaku yaitu UU No. 23 thn 1997 tentang manajemen lingkungan. Sebagian entitas sudah mengungkapkan dan melaporkan mengenai pelaporan berkelanjutan secara sukarela (volunteer) seperti PT.Astra Internasional, PT.Aneka Tambang, PT Jaya Ancol dan PT.Bukit Asam (Pusat et al., 2009). Regulasi dalam Undang-undang tersebut harus senantiasa dipatuhi dan diharapkan meningkatkan kepedulian entitas terhadap lingkungan.

Konsep sustainability tengah disosialisasikan dan diimplementasikan di mana-mana dan menjadi syarat wajib dalam going concern perusahaan. United Nation telah berhasil mempublikasi Sustainibility Depelopment Goals (SDGs) dalam 17 item pembangunan berkelanjutan yang bisa di akses oleh negara-negara di dunia dan di implementasikan dalam entitas di masing-masing negara. Sustainibility lebih nyata bisa di jabarkan dengan pelaksanaan konsep triple bottom line. Pelaporan Triple Bottom Line dapat diartikan "Pengukuran dan pelaporan kinerja ini dibutuhkan untuk membangun kepercayaan, menjawab kebutuhan dan memperkuat dialog dengan stakeholder, untuk mengurangi risiko perusahaan dan menjaga reputasi, untuk mendorong perbaikan internal yang berkelanjutan, serta untuk mencapai keuntungan kompetitif atas modal, buruh, pemasok dan pelanggan" (Pusat et al., 2009).

Konsep sustainability di Indonesia masih dalam tahap voluntary dimana baru sekitar 9\% entitas yang terdaftar di bursa efek telah menerbitkan laporan berkelanjutan baik include dengan annual report maupun dilakukan secara terpisah. Sementara itu untuk perusahaan yang di kategorikan dalam industri dasar dan kimia pulp and paper tercatat sekitar $8 \%$ yang menerbitkan laporan berkelanjutan. Entitas yang memiliki visi misi sustainability akan menerjemahkan konsep sustainability ke dalam strategi yang di implementasikan dalam setiap bagian operasi perusahaan. Setelah setiap aspek dan bagian dari perusahaan telah dijiwai oleh prinsip sustainability, selanjutnya entitas melakukan pengukuran kinerja dan mengkomunikasikan hal tersebut kepada para pemangku kepentingan dalam bentuk pelaporan kinerja yang terdiri dari tiga aspek yaitu ekonomi, sosial serta lingkungan hidup.(Rajafi \& Irianto, 2007).

Pelaporan kinerja lingkungan tidak akan terlaksana apabila sistem di dalam entitas belum sepenuhnya mendukung pada konsep sustainability. Karena proses ini tidak hanya sebagai output melainkan harus dimulai dari penyediaan bahan baku yang mengutamakan kelestarian lingkungan. Sistem Manajemen Lingkungan yang dituangkan dalam ISO 14001 bisa digunakan oleh entitas karena mudah bersinergi dengan sistem manajemen lainnya seperti ISO 45001 dan ISO 9001. Sayangnya belum semua entitas pulp and paper menerapkan sistem manajemen lingkungan, hanya sekitar 5 perusahaan dari 9 perusahaan yang sudah membuktikan diri mengunakan sistem manajemen lingkungan dengan di dapatnya ISO 14001. 
Ini menjadi isu krusial karena perusahaan Pulp and Paper bersentuhan langsung dengan lingkungan muali dari pengadaan bahan baku sampai proses akhir produk.

ISO 14001 memiliki keuntungan sebagai berikut yaitu keuntungan potensial langsung dan keuntungan potensial tidak langsung. Keuntungan potensial langsung terdiri dari reduksi penggunaan sumber daya bahan baku, reduksi dalam penggunaan energi, reduksi dalam bahan sisa, reduksi dalam keluhan dan tindak lanjut, menghindari denda dan penalti, dan menghindari pertanggung jawaban teradap regulasi (Chandra \& Christian, 2002).

Tujuan yang bersifat integral, dari penerapan Sistem Manajemen Lingkungan ISO 14001 merupakan standar internasional untuk mendukung perlindungan terhadap lingkungan dan pencegahan pencemaran yang tidak mengabaikan kebutuhan sosial ekonomi. Keuntungan SML ISO 14001 dari sisi ekonomi adalah memperbaiki kinerja lingkungan secara integral, menghasilkan kerangka kerja pencegahan polusi, meningkatkan efisiensi dan penghematan biaya potensial, dan meningkatkan nama baik dan citra perusahaan (Memed sueb \& Keraf, 2012).

Berdasarkan uraian pendahuluan di atas penelitian kali ini memiliki tujuan adalah untuk melihat secara kuantitas dan kualitas adakah kesamaan atau perbedaan antara pengungkapan sebelum (2014 s/d 2016) dan sesudah (2017 sd 2020) Sustainability Development Goals (SDGs).

\section{KAJIAN PUSTAKA}

\section{A. Manajemen Lingkungan}

Manajemen lingkungan diartikan sebagai kegiatan menyeluruh yang terdiri dari perencanaan, pelaksanaan, pengamatan, untuk mencegah pencemaran air, tanah, udara dan konservasi habitat serta keanekaragaman hayati. Manajemen lingkungan merupakan aspek-aspek dari fungsi-fungsi manajemen (termasuk perencanaan) yang mana dapat menentukan dan membawa pada implementasi kebijakan lingkungan (Sturm, 1998).

Fungsi Environment Management diupayakan untuk mengefisienkan semua unsur-unsur manajemen, yaitu man, money, mechine market dan lainnya. Dapat dilakukan melalui 4 fungsi manajemen Planning, Organizing, Acctuating dan Controling.(GR.Terry \&Leslie W rue, 2005).

Sistem Manajemen Lingkungan (EMS) merupakan kegiatan manajemen lingkungan yang dilakukan secara sistematis, prosedural, dan dapat diulang. Environment Management System menurut ISO 14001 adalah bagian dari sistem manajemen terintegrasi yang memiliki fungsi menjaga dan mencapai sasaran kebijakan lingkungan. Elemen kunci EMS yaitu pernyataan kebijakan terkait lingkungan dan merupakan bagian dari sistem manajemen perusahaan yang menyeluruh .(ISO, 2004).

Manajemen lingkungan dengan orientasi kebijakann terbagi menjadi:

1. Berorientasi pemenuhan (regulation compliance).

Pemenuhan di sini adalah kepatuhan terhadap regulasi dan peraturan pemerintah. Jangan sampai operasi peusahaan mencederai regulasi dan mengakibatkan kerugian atas keberlangsungan perushaan. Metoda yang dipakai adalah metode reaktif, ad hoc dan pendekatan secara end of pipe

2. Berorientasi setelah pemenuhan (beyond compliance). 
Tahapan berikutnya adalah berorientasi sesudah pemenuhan regulasi, karena pada tahapan pemenuhan dengan pendekatan 3 metode dianggap masih belum efisien dalam menangani masalah ligkungan. (Purwanto, 1998).

\section{B. Triple Bottom Line}

Dalam Cannibals with fork: the Triple Bottom Line of the 21s' Century Business tahun 1997 John Elkington mempopulerkan triple bottom line. Triple bottom line reporting adalah merupakan bentuk pelaporan lingkungan yang terdiri atas tiga aspek yaitu ekonomi, sosial, lingkungan. (Visser \& Elkington, 2013). "Triple Bottom Line reporting is a method of assessment of which the primary goal is toassess the performance of an organisation through reporting on relevant economic, environmental and social factor". (Marr: 2006).

Pengembangan pemikiran akuntansi konvensional salah satunya adalah Triple bottom line reporting. Dalam akuntansi konvensional pengungkapan dianggap hanya akan menambah biaya agensi menuju sustainability accounting. Tripple bottom line mendapat tempat di entitas karena dianggap mengakses esensi pengembangan berkelanjutan dengan mengukur keberhasilan perusahaan. (Budiawan, 2019)

"Manfaat dari konsep triple bottom line selain melaporkan kegiatan perusahaan dengan berbagai tujuan yaitu, membentuk hubungan yang baik dengan stakeholders, mengkondisikan resiko dengan mengidentifikasi area yang menjadi perhatian stakeholders dan bekerja sama dengan stakeholders secara proaktif, meningkatkan internal manajemen dan meningkatkan kontribusi perusahaan pada pembangunan yang peduli lingkungan" (Rajafi \& Irianto, 2007)

Terdapat tiga kategori dalam pengungkapan Triple bottom line. Pertama Tema Kemasyarakatan, dalam kategori ini yang dinilai yaitu, memberikan dukungan pada aktivitas masyarakat di lingkungan entitas, seperti aktivitas seni dan budaya, aktivitas olahraga, lembaga kerohanian, lembaga pendidikan, lembaga sosial lainnya serta dukungan pada fasilitas umum. Kategori kedua pada konsep Triple bottom line yaitu tema ketenagakerjaan. Tema ketenagakerjaan berkenaan dengan keselamatan dan kesehatan kerja, koperasi karyawan, kesejahteraan, pendidikan dan latihan, kesetaraan gender dalam kesempatan kerja, fasilitas peribadatan, serta cuti karyawan. Sedangkan tema lingkungan merupakan konsep yang ketiga. Tema lingkungan terdiri dari kebijakan lingkungan, sertifikasi lingkungan dan amdal, penggunaan energi, pencegahan/pengurangan polusi (pengelolaan limbah), dukungan pada konservasi Lingkungan, dukungan pada konservasi satwa, regulation rompliance, dan rating (Rajafi \& Irianto, 2007).

\section{Pengungkapan Management Environment Reporting}

Menurut (Wiseman, 1982) Pengungkapan sosial dan lingkungan berisi informasi tentang peraturan/regulasi, kebijakan terkait lingkungan, konservasi sumber daya alam baik flora maupun fauna, penghargaan dan sertifikat atas kepedulian terhadap lingkungan, biaya yang dilakukan perusahaan terkait dengan penangan lingkungan, aspek hukum (litigasi), atas kasus berkaitan dengan dampak lingkungan yang disebabkan oleh aktivitas perusahaan.

"Pengungkapan sebagai penyajian sejumlah informasi yang dibutuhkan untuk pengoperasian pasar modal yang efisien. Terdapat 2 jenis pengungkapan, pertama pengungkapan yang bersifat wajib (mandatory) yaitu pengungkapan informasi wajib dilakukan oleh perusahaan yang didasarkan pada peraturan atau standar tertentu, sedangkan yang kedua merupakan pengungkapan informasi melebihi persyaratan minimun dari peraturan yang berlaku."( Hendriksen: 1991)

Pengungkapan Management Environment Reporting merupakan bagian dari kebijakan lingkungan. "Kualitas kebijakan lingkungan tergantung pada tinggi rendahnya orientasi. Yang 
telah dikenal selama ini yaitu orientasi kebijakan memenuhi peraturan lingkungan (compliance oriented), dan yang berusaha melebihi standar peraturan tersebut (beyond compliance)".(Purwanto, 1998)

\section{Kerangka Pemikiran}

\section{Kuantitas Konten Di Website}

Undang-Undang Nomor 11 Tahun 2020 tentang Cipta Kerja ("UU Cipta Kerja”) yang menyederhankan syarat dan prosedur pendirian Perseroan Terbatas, "menyatakan bahwa Perseroan yang menjalankan kegiatan usahanya di bidang dan/atau berkaitan dengan sumber daya alam wajib melaksanakan Tanggung Jawab Sosial dan Lingkungan". Semenjak di berlakukannya perundangan tersebut entitas yang tercatat di bursa efek hanya memberikan laporan terkait lingkungan secara sukarela, sementara pengungkapan Corporate Sosial Resposibility (CSR) sudah dilakukan sesuai dengan regulasi yang ada. Selain karena jangka waktu pengungkapan baru di tetapkan di tahun 2017 dan masih mensyaratkan pelaporan secara sukarela sehingga entitas hanya mengugkapkan terkait manajemen lingkungannya sesuai denga kebijakan entitas masing-masing. Selebihnya entitas memiliki pilihan untuk mengungkapkan atau tidak mengungkapkan.

Laporan keuangan perusahan pulp dan paper menyampaikan laporan sustainability bersamaan dengan annual report dan dilaporkan terpisah yang bisa di akses publik melalui website perusahaan masing-masing. Dengan adanya Sustainability Development Goals (SDGs) sebagai aksi global maka apakah akan nampak perbedaan tema peyampaian informasi terkait management environment reporting kepada publik sebelum (2015 sd 2016) dan sesudah (2017 sd 2020) diberlakukannya sustainability reporting, hal ini akan kita coba teliti menggunakan pendekatan analisis konten.

\section{Kualitas Konten di Website}

Pengungkapan laporan lingkungan lebih banyak menggunakan sumber dari laporan keuangan yang menekankan pada kuantitas pengungkapannya tetapi tidak melihat apakah pengungkapan tersebut sudah sesuai dengan standar yang ada. Terkait dengan hal tersebut karena sumber data yang digunakan sempit dan tidak bisa berkembang sehingga diperlukan metode penelitian yang lebih bisa membaca baik secara implisit maupun eksplisit terkait dengan pengungkapan pertanggungjawaban lingkungan yang sudah dan akan dilakukan perusahaan.

"There are several limitations in the use of content analysis (Milne \& Adler, 1999)". "The first is the recognition that it captures quantity of disclosure (in terms of frequency and volume of reporting) rather than quality characteristics. The second is that it is subjective, in that it is capturing various narratives as a representation of SER'.(Guthrie et al., 2012)

Penelitian ini mencoba menggunakan analisis isi untuk melampaui batasan terkait analisis isi hanya bisa mengungkapkan sisi kuantitas daripada kualitas. Cara yang digunakan adalah mencoba menggabungkan metodologi penelitian analisis isi dengan uji beda dengan indeks sebagai dasar penilaiannya. Hal tersebut sesuai dengan penelitian "The second approach is the use of disclosure indices to assess, compare and explain differences in the extent and comprehensiveness of disclosure in annual reports" (Marston \& Shrives, 1991). " A disclosure index is a research instrument comprising aseries of pre-selected items which, when scored, provide a measure that indicates a level of disclosure in the specific context for which the index was devised". (Coy et al., 1995). 
Emiten pulp and paper dalam hal sustainability disclosure baik dari sisi sosial maupun lingkungan masih menggunakan General Reporting Initiation (GRI) untuk pelaporannya.

\section{Pengembangan Hipotesis}

Penelitian terkait dengan penggunaan analisis isi dalam hal pengungkapan laporan manajemen lingkungan masih belum banyak dilakukan oleh para peneliti. Peneliti lebih menitik beratkan pada penggunaan legitimacy theory dengan metodologi penelitian secara sekunder kuantitatif dengan sumber data dari laporan tahunan (Deegan, 2002) "menggunakan teori legitimasi untuk mencoba menjelaskan perubahan sistematis dalam kebijakan pengungkapan lingkungan laporan tahunan perusahaan". Kemudian (Patten, 1992) mencoba "memusatkan perhatian pada perubahan tingkat pengungkapan lingkungan yang dilakukan oleh perusahaan minyak Amerika Utara dengan meningkatkan jumlah pengungkapan lingkungan pada laporan tahunannya”. Dalam penelitian ini, hipotesis yang di ajukan adalah

H1 : Ada perbedaan tema konten environment management reporting disclosure sebelum dan sesudah sustainability development goals (SDGs).

\section{METODE PENELITIAN}

\section{A. Desain Analisis Isi}

Penelitian ini menggunakan metode analisis konten kuantitatif (quantitave content analysis). "Analisis isi kuantitatif adalah analisis yang dipakai untuk mengukur aspek-aspek tertentu dari berita yang dilakukan secara kuantitatif, prosedurnya adalah dengan mengukur atau menghitung aspek dari berita itu dan menyajikannya secara kuantitatif. Analisis isi hanya dipakai hanya memfokuskan pada bahan yang tersurat saja"(Eriyanto, 2011).

Prosedur dasar dan rancangan penelitian serta pelaksanaan studi analisis konten terdiri atas 6 tahapan langkah, yaitu "(1) merumuskan pertanyaan penelitian dan hipotesisnya, (2) melakukan sampling terhadap sumber-sumber data yang telah dipilih, (3) pembuatan kategori yang dipergunakan dalam analisis, (4) pendataan suatu sampel dokumen yang telah dipilih dan melakukan pengkodean, (5) pembuatan skala dan item berdasarkan kriteria tertentu untuk pengumpulan data, dan (6) interpretasi/ penafsiran data yang diperoleh". (AM Irfan Taufan Asfar, 2019).

Analisis konten/isi hanya memfokuskan pada bahan dari tema pengungkapan manajemen lingkungan yang bisa terbaca secara eksplisit di website masing-masing entitas. Peneliti hanya mengcoding apa yang dilihat atau di baca dalam website masing-masing perusahaan. Adapun tahapan analisis isi dalam research kali ini adalah sebagai berikut:

1. Menentukan Unit Analisis kemudian menentukan Hipotesis

a. Unit pencatatan

- Unit Fisik ; Berapa panjang narasi pengungkapan, Berapa kali kegiatan lingkungan dilaksanakan

- Unit Sintaksis ; Frekuensi penggunaan kata "Lingkungan"

- Unit Tematik ; Topik konten di Website

b. Unit Sample ; Management Environment Reporting 
2. Klasifikasi Triple Bottom Line menjadi 8 indikator yaitu kebijakan lingkungan, sertifikasi lingkungan dan AMDAL, Penggunaan Energi, Pencegahan/pengurangan polusi (pengelolaan limbah), Dukungan pada konservasi Lingkungan, Dukungan pada konservasi satwa, Regulation Compliance, dan Rating.

3. Koding ; Memberi tanda check list pada item-item pengungkapan Management Environment Reporting dan memberi koding untuk setiap pengungkapan. Pengukuran dengan menggunakan skala dummy, dengan skor 0 apabila tidak diungkapkan dan skor 1 apabila diungkapkan. Skor maksimal 72 untuk score sebelum sustainability yang didapat dari 8 indikator kebijakan lingkungan dikali dengan 3 tahun (2014, 2015 dan 2016) dikali dengan 3 item penempatan pengungkapan konten yaitu penempatan konten (headline, halaman depan, tidak headline, halaman dalam, dan halaman khusus), tema konten, dan penggambaran konten (Eriyanto, 2011). Skor maksimal 96 untuk score sesudah sustainability didapat dari 8 indikator dikali 4 tahun (2017,2018,2019 dan 2020) dikali dengan 3 item penempatan pengungkapan konten.

4. Penjumlahan hasil scoresing pada tiap indikator pengungkapan

5. Mempersentasikan setiap skor pada tiap bagian pengungkapan. Semakin besar persentasi menandakan indek perusahaan juga besar. Entitas yang mendapatkan indeks yang lebih tinggi mengindikasikan bahwa entitas tersebut melakukan praktik pengungkapan yang lebih komprehensif dan terintegrasi.

6. Melakukan pengukuran reliabelitas dan validitas

\section{B. Pemilihan Media dan Sampel}

Media yang diteliti adalah website perusahaan pulp and paper di Indonesia yang terdiri dari sembilan perusahaan yang mencatatkan diri di Bursa Efek Indonesia. Penelitian ini memiliki sampel jenuh dimana 9 website perusahaan pulp and paper di analisa baik sebelum diberlakukannya konsep sustainability maupun sesudah diberlakukannya konsep sustaiability oleh Otoritas Jasa Keuangan (OJK).

\section{Validitas Alat Ukur}

"Arti penting validitas dikatakan sebagai kualitas hasil penelitian yang memebawa sesorang untuk meyakini bahwa fakta-fakta yang ada tidak dapat ditentang". (Krippendorff, 2004). Penelitian ini ingin menguji suatu hipotesis tertentu maka validitas yang dipakai adalah validitas konstruk. "Validitas kontruk adalah validitas yang melihat apakah alat ukur disusun atau diturunkan dari suatu kerangka teori tertentu" (Neuendorf 2002:117). Alat ukur untuk penelitian ini disusun dengan ketat berdasarkan suatu kontruksi sustainability development goals (SDGs) yang di turunkan menjadi triple bottom line dan diturunkan kembali pada tema lingkungan yang disusun oleh Marr: 2006 dalam buku "Cannibals with fork: the Triple Bottom Line of the 21s' Century Business".

\section{Reliabilitas Alat Ukur}


"Reliabilitas alat ukur yang digunakan adalah reproduksibilitas yang merupakan derajat sebuah alat ukur dapat menghasilkan temuan yang sama dalam berbagai keadaan yang berbeda". Menurut Krippendorff (1980:2004) "membagi tiga jenis reliabilitas yakni stabilitas, reproduksibilitas dan akurasi”.

Penelitian ini dilakukan dengan melibatkan 2 coder dengan menggunakan sejumlah variabel yang ingin diketahui lewat analisis isi dengan pendekatan formula Holsti. Sebelum lembar coding dipakai dilakukan terlebih dahulu pengujian reliabilitasnya.

Pengujian reliabilitas dilakukan terhadap 9 website pulp and paper production dari tahun 2014 sampai dengan 2020 berjumlah 63 konten analisa. Angka realibilitas minimum yang ditoleransi adalah $70 \%$. Artinya jika hasil perhitungannya $70 \%$ berarti alat ukur ini benarbenar reliabel. Dalam penelitian ini yang bertindak sebagai coder adalah peneliti 1 (coder 1 ) dan peneliti 2 (coder 2).

Berikut ini adalah uji reliabilitas tema pengungkapan Lingkungan di website perusahaan pulp and paper yang di lakukan oleh dua coder:

Tabel 1

Reliabilitas antar coder Tema Pengungkapan Lingkungan di Website

\begin{tabular}{|c|c|c|c|c|}
\hline No & Produsen & CODER 1 & CODER 2 & Setuju/ Tidak Setuju \\
\hline \multicolumn{5}{|c|}{ Tahun 2014} \\
\hline 1 & Alkindo Naratama, tbk & 1 & 1 & $\mathrm{~S}$ \\
\hline 2 & Fajar Surya Wisesa, tbk & 1 & 1 & $\mathrm{~S}$ \\
\hline 3 & Indah Kiat Pulp \& paper,tbk & 1 & 1 & $\mathrm{~S}$ \\
\hline 4 & Toba Pulp Lestari, tbk & 0 & 0 & TS \\
\hline 5 & $\begin{array}{l}\text { Kertas Basuki Rahmat } \\
\text { Indonesia, tbk }\end{array}$ & 1 & 1 & $S$ \\
\hline 6 & $\begin{array}{l}\text { Kedawung Setia Industrial, } \\
\text { tbk }\end{array}$ & 1 & 1 & $S$ \\
\hline 7 & Suparma, tbk & 1 & 1 & $\mathrm{~S}$ \\
\hline 8 & Sriwahana Adityakarta, tbk & 1 & 1 & $\mathrm{~S}$ \\
\hline 9 & Pabrik Kertas Tjiwi Kimia, tbk & 1 & 1 & $\mathrm{~S}$ \\
\hline \multicolumn{2}{|r|}{ Tahun 2015} & CODER 1 & CODER 2 & Setuju/ Tidak Setuju \\
\hline 1 & Alkindo Naratama, tbk & 1 & 1 & $\mathrm{~S}$ \\
\hline 2 & Fajar Surya Wisesa, tbk & 1 & 1 & $\mathrm{~S}$ \\
\hline 3 & Indah Kiat Pulp \& paper,tbk & 1 & 1 & $\mathrm{~S}$ \\
\hline 4 & Toba Pulp Lestari, tbk & 1 & 0 & TS \\
\hline 5 & $\begin{array}{l}\text { Kertas Basuki Rahmat } \\
\text { Indonesia, tbk }\end{array}$ & 1 & 1 & $S$ \\
\hline 6 & $\begin{array}{l}\text { Kedawung Setia Industrial, } \\
\text { tbk }\end{array}$ & 1 & 1 & $S$ \\
\hline 7 & Suparma, tbk & 1 & 1 & $\mathrm{~S}$ \\
\hline 8 & Sriwahana Adityakarta, tbk & 1 & 1 & $\mathrm{~S}$ \\
\hline 9 & Pabrik Kertas Tjiwi Kimia, tbk & 1 & 1 & $\mathrm{~S}$ \\
\hline \multicolumn{5}{|c|}{ Tahun 2016} \\
\hline 1 & Alkindo Naratama, tbk & 1 & 1 & $S$ \\
\hline 2 & Fajar Surya Wisesa, tbk & 1 & 1 & $\mathrm{~S}$ \\
\hline
\end{tabular}


Journal Accounting and Finance

Edisi Vol. 5, No. 2, September 2021

Universitas Telkom

\begin{tabular}{|c|c|c|c|c|}
\hline 3 & Indah Kiat Pulp \& paper,tbk & 1 & 1 & $\mathrm{~S}$ \\
\hline 4 & Toba Pulp Lestari, tbk & 1 & 0 & TS \\
\hline 5 & $\begin{array}{l}\text { Kertas Basuki Rahmat } \\
\text { Indonesia, tbk }\end{array}$ & 1 & 1 & $S$ \\
\hline 6 & $\begin{array}{l}\text { Kedawung Setia Industrial, } \\
\text { tbk }\end{array}$ & 1 & 1 & $S$ \\
\hline 7 & Suparma, tbk & 1 & 1 & $\mathrm{~S}$ \\
\hline 8 & Sriwahana Adityakarta, tbk & 1 & 1 & $\mathrm{~S}$ \\
\hline 9 & Pabrik Kertas Tjiwi Kimia, tbk & 1 & 1 & $S$ \\
\hline \multicolumn{2}{|r|}{ Tahun 2017} & CODER 1 & CODER 2 & Setuju/ Tidak Setuju \\
\hline 1 & Alkindo, tbk & 2 & 2 & $\mathrm{~S}$ \\
\hline 2 & Fajar Surya, tbk & 2 & 2 & $\mathrm{~S}$ \\
\hline 3 & Indah Kiat,tbk & 2 & 2 & $\mathrm{~S}$ \\
\hline 4 & Toba Pulp Lestari, tbk & 0 & 0 & TS \\
\hline 5 & $\begin{array}{l}\text { Kertas Basuki Rahmat } \\
\text { Indonesia, tbk }\end{array}$ & 1 & 1 & $S$ \\
\hline 6 & $\begin{array}{l}\text { Kedawung Setia Industrial, } \\
\text { tbk }\end{array}$ & 1 & 1 & $S$ \\
\hline 7 & Suparma, tbk & 1 & 1 & $S$ \\
\hline 8 & Sriwahana Adityakarta, tbk & 1 & 1 & $\mathrm{~S}$ \\
\hline \multirow[t]{2}{*}{9} & Pabrik Kertas Tjiwi Kimia, tbk & 2 & 2 & $S$ \\
\hline & Tahun 2018 & CODER 1 & CODER 2 & Setuju/ Tidak Setuju \\
\hline 1 & Alkindo Naratama, tbk & 2 & 2 & $\mathrm{~S}$ \\
\hline 2 & Fajar Surya Wisesa, tbk & 1 & 1 & $S$ \\
\hline 3 & Indah Kiat Pulp \& paper,tbk & 2 & 2 & $\mathrm{~S}$ \\
\hline 4 & Toba Pulp Lestari, tbk & 2 & 2 & $\mathrm{~S}$ \\
\hline 5 & $\begin{array}{l}\text { Kertas Basuki Rahmat } \\
\text { Indonesia, tbk }\end{array}$ & 1 & 1 & $S$ \\
\hline 6 & $\begin{array}{l}\text { Kedawung Setia Industrial, } \\
\text { tbk }\end{array}$ & 1 & 1 & $S$ \\
\hline 7 & Suparma, tbk & 1 & 1 & $\mathrm{~S}$ \\
\hline 8 & Sriwahana Adityakarta, tbk & 1 & 1 & $S$ \\
\hline \multirow[t]{2}{*}{9} & Pabrik Kertas Tjiwi Kimia, tbk & 2 & 2 & $S$ \\
\hline & Tahun 2019 & CODER 1 & CODER 2 & Setuju/ Tidak Setuju \\
\hline 1 & Alkindo, tbk & 2 & 2 & $\mathrm{~S}$ \\
\hline 2 & Fajar Surya, tbk & 1 & 1 & $\mathrm{~S}$ \\
\hline 3 & Indah Kiat,tbk & 2 & 2 & $\mathrm{~S}$ \\
\hline 4 & Toba Pulp Lestari, tbk & 2 & 2 & $S$ \\
\hline 5 & $\begin{array}{l}\text { Kertas Basuki Rahmat } \\
\text { Indonesia, tbk }\end{array}$ & 1 & 1 & $S$ \\
\hline 6 & $\begin{array}{l}\text { Kedawung Setia Industrial, } \\
\text { tbk }\end{array}$ & 1 & 1 & $S$ \\
\hline 7 & Suparma, tbk & 1 & 1 & $S$ \\
\hline 8 & Sriwahana Adityakarta, tbk & 1 & 1 & $S$ \\
\hline 9 & Pabrik Kertas Tjiwi Kimia, tbk & 2 & 2 & $\mathrm{~S}$ \\
\hline
\end{tabular}

https://journals.telkomuniversity.ac.id/jaf

E-ISSN 2581-1088 


\begin{tabular}{|c|l|c|c|c|}
\hline \multicolumn{2}{|c|}{ Tahun 2020 } & CODER 1 & CODER 2 & Setuju/ Tidak Setuju \\
\hline 1 & Alkindo, tbk & 2 & 2 & $\mathrm{~S}$ \\
\hline 2 & Fajar Surya, tbk & 1 & 1 & $\mathrm{~S}$ \\
\hline 3 & Indah Kiat, tbk & 2 & 2 & $\mathrm{~S}$ \\
\hline 4 & Toba Pulp Lestari, tbk & 2 & 2 & $\mathrm{~S}$ \\
\hline 5 & $\begin{array}{l}\text { Kertas Basuki Rahmat } \\
\text { Indonesia, tbk }\end{array}$ & 1 & 1 & $\mathrm{~S}$ \\
\hline & $\begin{array}{l}\text { Kedawung Setia Industrial, } \\
\text { tbk }\end{array}$ & 1 & 1 & $\mathrm{~S}$ \\
\hline 7 & Suparma, tbk & 1 & 1 & $\mathrm{~S}$ \\
\hline 8 & Sriwahana Adityakarta, tbk & 1 & 1 & $\mathrm{~S}$ \\
\hline 9 & Pabrik Kertas Tjiwi Kimia, tbk & 2 & 2 & $\mathrm{~S}$ \\
\hline
\end{tabular}

Tabel 2

Uji Reliabilitas

\begin{tabular}{|l|c|}
\hline \multicolumn{1}{|c|}{ Penilaian Coder } & Tema Pengungkapan Lingkungan di website \\
\hline \hline Setuju & 59 \\
\hline Tidak Setuju & 4 \\
\hline
\end{tabular}

Dalam analisis ini, penulis menggunakan formula Holsti untuk mengukur realibilitas antar coder. Formula Holsti ini pertama kali diperkenalkan oleh R. Holsti. Relibilitas ini ditunjukkan dalam presentase persetujuan berapa besar presentase persamaan antara coder ketika menilai suatu isi (Eriyanto 2011:290). Berikut perhitungan reliabilitas menggunakan formula holsti:

$$
\begin{aligned}
& \text { FORMULA HOLSTI }=2 \mathrm{M} /(\mathrm{N} 1+\mathrm{N} 2) \\
& =2(59) / 63+63=0,94=94 \%
\end{aligned}
$$

Keterangan :

$\mathrm{M}=$ Jumlah coding yang sama

N1 = Jumlah coding yang dibuat oleh coder 1

N2 = Jumlah coding yang dibuat oleh coder2 . (Eriyanto 2011:290).

Tabel 3

\section{Realibilitas Variabel}

\begin{tabular}{|l|l|c|}
\hline Variabel & \multicolumn{1}{|c|}{ Indikator } & Reliabilitas Antar Coder \\
\hline \hline \multirow{4}{*}{} & Penempatan konten & $94 \%$ \\
\cline { 2 - 3 } & Tema konten & $94 \%$ \\
\cline { 2 - 3 } & Penggambaran konten & $94 \%$ \\
\hline \multirow{4}{*}{} & Penempatan konten & $93 \%$ \\
\cline { 2 - 3 } & Tema konten & $90 \%$ \\
\cline { 2 - 3 } & Penggambaran konten & $87 \%$ \\
\hline
\end{tabular}




\begin{tabular}{|l|l|c|}
\hline Penggunaan Energi & Penempatan konten & $94 \%$ \\
\cline { 2 - 3 } & Tema konten & $94 \%$ \\
\cline { 2 - 3 } & Penggambaran konten & $94 \%$ \\
\hline \multirow{5}{*}{} & Penempatan konten & $92 \%$ \\
\cline { 2 - 3 } & Tema konten & $93 \%$ \\
\cline { 2 - 3 } & Penggambaran konten & $90 \%$ \\
\hline \multirow{5}{*}{} & Penempatan konten & $94 \%$ \\
\cline { 2 - 3 } & Tema konten & $94 \%$ \\
\cline { 2 - 3 } & Penggambaran konten & $87 \%$ \\
\hline \multirow{5}{*}{} & Penempatan konten & $94 \%$ \\
\cline { 2 - 3 } & Tema konten & $80 \%$ \\
\cline { 2 - 3 } & Penggambaran konten & \\
\hline & Penempatan konten & $94 \%$ \\
\cline { 2 - 3 } & Tema konten & $90 \%$ \\
\cline { 2 - 3 } & Penggambaran konten & \\
\hline & Penempatan konten & $94 \%$ \\
\cline { 2 - 3 } & Tema konten & $90 \%$ \\
\cline { 2 - 3 } & Penggambaran konten & $90 \%$ \\
\hline
\end{tabular}

\section{E. Uji Beda (Chi Square)}

Uji beda ini dilakukan untuk melihat perbedaan pada dua aspek isi dan waktu. Analisis data dipakai untuk mengananalisis apakah ada perbedaan antara tema konten website sebelum dan sesudah sustainability reporting. Teknik statistik yang dipakai adalah chi square, untuk menguji perbedaan dalam skala nominal yaitu berupa penghitungan frekuensi pemunculan/ pengungkapan tertentu yaitu konten atau isi.

\section{HASIL PENELITIAN}

Pengungkapan Environment Management Disclosure di 9 website perusahan pulp and paper lebih ke arah naratif kualitatif dan kuantitatif non moneter. Analisis konten naratif kualitatif bisa dijabarkan dengan pendekatan unit fisik dan unit tematik. Sedangkan pengungkapan kuantitatif non moneter menggunakan pendekatan unit sintaksis.

Analisa yang digunakan untuk mengukur pengungkapan Environment Management Reporting dalam penelitian ini menggunakan tiga pendekatan yaitu unit fisik, unit sintaksis dan unit tematik dengan triple bottom sebagai varibel yang di ukurnya.

Tabel tiga menunjukan jumlah pengungkapan environment management reporting oleh 9 perusahaan pulp dan paper sebelum dan sesudah sustainability dengan pendekatan unit tematik triple bottom line yang di tuangkan dalam persen. Periode waktu sebelum sustainability adalah berjumlah 3 tahun yaitu tahun 2014, 2015 dan 2016 sedangkan periode waktu sesudah sustainability adalah 4 tahun yaitu 2017, 2018, 2019 dan 2020 sebagai berikut:

Tabel 4

Perbandingan Pengungkapan Management Environment Reporting Sebelum dan Sesudah Sustainability dalam Persen 


\begin{tabular}{|c|c|c|c|c|}
\hline Variabel & Indikator & Kategori & $\begin{array}{c}\text { Sebelum } \\
\%\end{array}$ & Sesudah \% \\
\hline & Penempatan konten & $\begin{array}{l}\text { 1. Headline } \\
\text { 2. Halaman Depan } \\
\text { 3. Tidak Headline, } \\
\text { 4. Halaman dalam, } \\
\text { 5. Halaman Khusus }\end{array}$ & 100 & 100 \\
\hline & Tema konten & $\begin{array}{l}\text { 1. Sustainability } \\
\text { 2. Environment, } \\
\text { 3. Annual Report }\end{array}$ & $\begin{array}{l}46,2 \\
53,8\end{array}$ & 100 \\
\hline & Penggambaran konten & $\begin{array}{l}\text { 1. Progresif, } \\
\text { 2. Konservatif }\end{array}$ & 100 & 100 \\
\hline & Penempatan konten & $\begin{array}{l}\text { 1. Headline, } \\
\text { 2. Halaman Depan, } \\
\text { 3. Tidak Headline } \\
\text { 4. Halaman dalam, } \\
\text { 5. Halaman Khusus }\end{array}$ & $\begin{array}{l}50 \\
50\end{array}$ & $\begin{array}{c}13.6 \\
\\
36,4 \\
50\end{array}$ \\
\hline & Tema konten & $\begin{array}{l}\text { 1. Sustainability, } \\
\text { 2. Environment, } \\
\text { 3. Annual Report }\end{array}$ & $\begin{array}{l}25 \\
75\end{array}$ & 100 \\
\hline & Penggambaran konten & $\begin{array}{l}\text { 1. Progresif, } \\
\text { 2. Konservatif }\end{array}$ & 100 & 100 \\
\hline & Penempatan konten & $\begin{array}{l}\text { 1. Headline, } \\
\text { 2. Halaman Depan, } \\
\text { 3. Tidak Headline, } \\
\text { 4. Halaman dalam, } \\
\text { 5. Halaman Khusus }\end{array}$ & 40 & $\begin{array}{l}27,2 \\
72,8\end{array}$ \\
\hline & Tema konten & $\begin{array}{l}\text { 1. Sustainability, } 2 . \\
\text { Environment, } 3 . \\
\text { Annual Report }\end{array}$ & $\begin{array}{l}40 \\
60\end{array}$ & 100 \\
\hline & Penggambaran konten & $\begin{array}{l}\text { 1. Progresif, } \\
\text { 2. Konservatif }\end{array}$ & 100 & 100 \\
\hline & Penempatan konten & $\begin{array}{l}\text { 1. Headline, } \\
\text { 2. Halaman Depan, } \\
\text { 3. Tidak Headline, } \\
\text { 4. Halaman dalam, } \\
\text { 5. Halaman Khusus }\end{array}$ & 50 & 100 \\
\hline & Tema konten & $\begin{array}{l}\text { 1. Sustainability, } \\
\text { 2. Environment, } \\
\text { 3. Annual Report }\end{array}$ & $\begin{array}{l}25 \\
75\end{array}$ & $\begin{array}{l}27,2 \\
72,8\end{array}$ \\
\hline & Penggambaran konten & $\begin{array}{l}\text { 1. Progresif, } 2 . \\
\text { Konservatif }\end{array}$ & 100 & 100 \\
\hline & Penempatan konten & $\begin{array}{l}\text { 1. Headline, } \\
\text { 2. Halaman Depan, } \\
\text { 3. Tidak Headline, } \\
\text { 4. Halaman dalam, } \\
\text { 5. Halaman Khusus }\end{array}$ & 100 & 100 \\
\hline
\end{tabular}




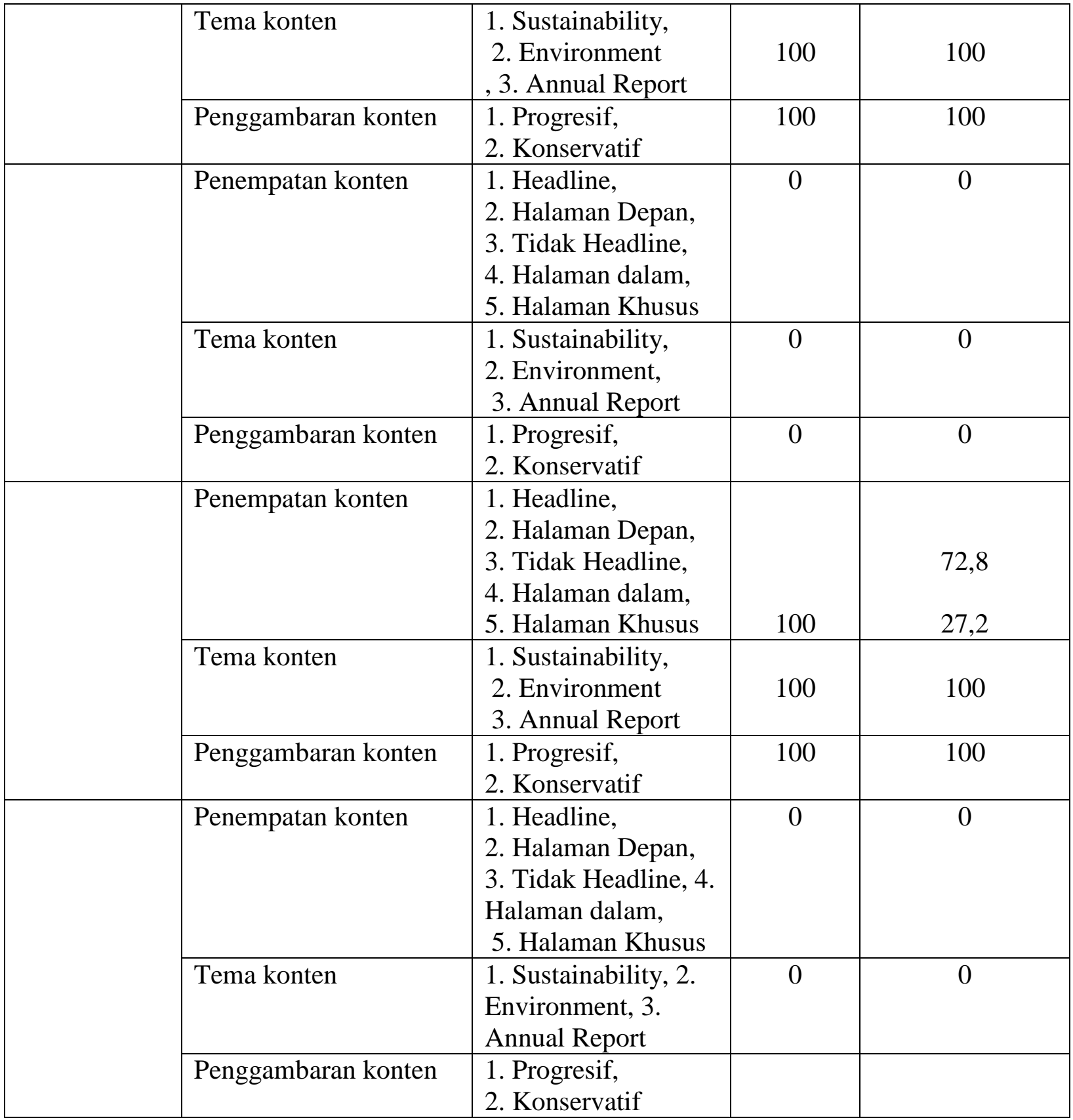

Pengolahan data dilakuakan menggunakan SPSS versi 25 dengan alat uji non parametik Kruskal Willis. Adapun hasil uji beda menggunakan chi square analysis dengan Degree of Freedom $(\mathrm{DF}=7)$, dengan chi square 3,608 $<\mathbf{1 4 , 0 6 7}$ berarti tidak ada perbedaan signifikan antara pengungkapan sebelum dan sesudah sustainability yang artinya $\mathrm{H} 0$ diterima dan $\mathrm{H} 1$ ditolak.

\section{PEMBAHASAN}

Pengungkapan Environment Management Reporting oleh entitas pulp and paper sebagian sudah di lakukan secara sukarela sebelum Sustainabiliy Development Goals (SDGs) menjadi rencana aksi global dan mulai di adopsi oleh Perusahaan-perusahaan di Indonesia. Hal tersebut merupakan rasa tanggung jawab entity terhadap ekonomi, lingkungan, dan sosial. 
Pengungkapan yang dilakukan sebelum dan sesudah diberlakukannya sustainability development goals (SDGs) ternyata tidak memiliki perbedaan secara konten pengungkapannya.

Ini bisa dilihat dari hasil uji beda antara konten pengungkapan sebelum dan sesudah di sosialisasikannya sustainability development goals (SDGs). Hal tersebut mengindikasikan secara kuantitas maupun kualitas pengungkapan tidak jauh beda perkembangannya dari tahun ke tahun.

Secara kuantitas entitas pulp and paper sebelum Sustainability Development Goals (SDGs) sudah mengungkapkan terkait tanggung jawabnya terhadap lingkungan yang disusun bersamaan dengan annual report yang dilaporkan setiap tahun. Adapun sesudah Sustainability Development Goals (SDGs) pengungkapan masih lebih banyak diungkapkan dalam laporan Sustainability yang disusun bersamaan dengan laporan keuangan dan masih dalam satu website yang bisa di akses publik, hanya PT. Indah, tbk dan PT. Tjiwi Kimia, tbk yang membuat laporan Sustainability yang disusun terpisah di website terpisah dari laporan tahunan. Hal tersebut karena kedua perseroan tersebut memiliki konsistensi dalam hal Sustainability dan itu di buktikan dengan banyaknya sertifikat yang didapat terkait dengan Sustainability dan Environment. Adapun konsistensi pengungkapan yang dilakukan oleh 9 perusahaan pulp and paper masih belum konsisten yaitu hanya sekitar 66\% yang sudah mengungkapkan laporan lingkungan secara konsisten dalam periode 2017 sampai dengan 2020. Hal ini terlihat dari ketersediaan informasi terkait pelaporan lingkungan yang belum di laporkan tiap tahun seperti Sriwahana Adityakarta,tbk yang hanya mengungkapan pelaporan lingkungan di tahun 2017 sementara itu Kedawung tidak membuat laporan di tahun 2017 dan konsisten melaporkan di tahun 2018 sampai 2020. Terdapat dua variabel pengungkapan environment management reporting yang sama sekali tidak di ungkapkan dan kemungkinan tidak ada kegiatan yang terkait dengan dua variabel tersebut yaitu dukungan konservasi hewan dan rating. Hal tersebut kemungkinan karena tidak ada afiliasi langsung antara kegiatan perusahaan dengan konservasi hewan dan tidak adanya alokasi dana yang dianggarkan terkait dengan hal tersebut baik sebelum maupun sesudah Sustainability Development Goals (SDGs).

Pengungkapan manajemen lingkungan yang dilakukan perusahaan pulp and paper masih menggunakan pedoman dari General Reporting Initiation (GRI). Kualitas pengungkapan sebelum dan sesudah Sustainability Development Goals (SDGs) tidak jauh berbeda dari tahun ke tahun. Unit fisik, unit sintaksis dan unit tematik digunakan untuk menganalisa pengungkapan dari sisi kualitas dan hasilnya tidak jauh berbeda dengan standar pembanding minimal pengungkapan yaitu POJK N0. 51 tahun 2017. Hanya dari variabel konservasi hewan dan rating belum di ungkapkan sesuai dengan pedoman yang ada.

Hasil ini sejalan dengan teori legitimasi, dimana dalam "teori legitimasi menegaskan bahwa organisasi terus berupaya memastikan bahwa mereka dianggap beroperasi dalam batasbatas dan norma-norma masyarakat masing-masing, yaitu mereka berusaha untuk memastikan bahwa aktivitas mereka dianggap oleh pihak luar sebagai sah" (Imam Ghozali, 2020). Sejalan juga dengan pendapat yang di ungkapkan (Purwanto, 1998) "Jika kita mengasumsikan tujuan lingkungan akhir bagi perusahaan adalah pengembangan berkelanjutan (sustainable development) di semua operasi perusahaan, kita harus peduli pada fakta bahwa adalah tidak mungkin bagi perusahaan untuk mencapai tujuan berkelanjutan tersebut dalam masyarakat non-sustainable dan jika hanya sedikit perusahaan mulai berpikir tentang pentingnya kondisi lingkungan setelah EMS atau ISO (beyond EMS). Sehingga langkah paling logis dan efektif yang dapat dilakukan perusahaan sebagai salah seorang pelaku dalam masyarakat adalah melakukan langkah integrasi kebijakan lingkungan dalam bisnisnya dengan prinsip kualitas".

Secara empiris ternyata selepas diberlakukannya Sustainibility Depelopment Goals (SDGs) tidak ada perubahan kuantitas dan kualitas pengungkapan environment management reporting di dalam website perusahaan pulp and paper yang ada di Indonesia, karena entitas 
sudah melaporkan lebih awal manajemen lingkungannya dengan pendekatan General Reporting Initiation (GRI).

\section{KESIMPULAN}

Secara umum pengungkapan Environment Management Reporting di website perusahan pulp and paper sudah dilakukan secara sukarela sebelum bergaungnya konsep Sustainability Development Goals (SDGs) di Indonesia yang merupakan bentuk kesadaran entitas terhadap tanggung jawabnya pada lingkungan, sosial dan ekonomi. Berbarengan dengan Sustainability Development Goals (SDGs) yang mulai di implementasikan di Indonesia, sistem manajemen lingkungan (EMS) menjadi acuan pelaksanaan manajemen lingkungan dengan bentuk pengakuan sertifikat ISO 14001. Perusahaan pulp and paper yang ada di Indonesia Sebagian besar sudah mendapatkan ISO 14001 manjemen lingkungan sebagai bentuk ketaatan terhadap peraturan yang berlaku di Indonesia sekaligus dukungan terhadap Sustainability Development Goals (SDGs).

Maka dapat disimpulkan bahwa pengungkapan Environment Management Reporting Disclosure yang dilakukan oleh perusahaan kertas and paper di Indonesia sudah dilakukan terencana dan berprogres.

\section{SARAN}

1. POJK 51 tahun 2017 belum mengungkapkan secara rinci dan terstruktur dalam hal pengungkapan Environment Management Reporting Disclosure untuk keseragaman dalam hal penyampaian informasi sustainability kepada pihak-pihak yang berkepentingan.

2. Regulasi terkait Environment Management Reporting Disclosure harus lebih bisa diimplementasikan untuk semua jenis entitas baik yang terdaftar di Bursa Efek ataupun tidak.

3. Dalam penelitian ini indikator pengungkapan yang paling rendah adalah pada pengungkapan konservasi hewan dan rating, ini bisa di jadikan penelitian lebih lanjut oleh peneliti yang akan datang dengan mengambil sampel pada perusahaan sektor lainnya yang ada di bursa efek.

\section{DAFTAR PUSTAKA}

Budiawan, S. (2019). the Analysis of Triple Bottom Line Disclosure in the Implementation of Environmental Management Accounting in Mining Industry Analisis Pengungkapan Triple Bottom Line Dalam Penerapan Akuntansi Manajemen Lingkungan Pada Industri Pertambangan. 22-30.

Chandra, H. P., \& Christian, D. (2002). Analisa Sistem Manajemen Lingkungan (ISO 14000) Dan Kemungkinan Implementasinya Oleh Para Kontraktor Kelas A Di Surabaya. Dimensi Teknik Sipil, 4(2), 77-84.

Coy, R. C., Michopoulos, Y., \& Wilkinson, J. P. T. (1995). Environmental Impact of Lubricants. Tribology Series. https://doi.org/10.1016/S0167-8922(08)70612-6

Deegan, C. (2002). Introduction: The legitimising effect of social and environmental disclosures - a theoretical foundation. Accounting, Auditing \& Accountability Journal, 15(3), 282-311. https://doi.org/10.1108/09513570210435852 
Eriyanto. (2011). Analisis Isi: Pengantar Metodologi untuk Penenlitian Ilmu Komunikasi dan ilmu-ilmu sosial lainnya. Analisis Isi: Pengantar Metodologi Untuk Penenlitian Ilmu Komunikasi Dan Ilmu-Ilmu Sosial Lainnya.

Guthrie, J., Abeysekera, I., Ekonomi, F., \& Sydney, U. (2012). Analisis konten sosial , pelaporan lingkungan: apa yang baru? 2006.

ISO. (2004). IS0 14001: Environmental management systems - Requirements with guidance for use. In Order A Journal On The Theory Of Ordered Sets And Its Applications.

Krippendorff, K. (2004). Reliability in content analysis: Some common misconceptions and recommendations. Human Communication Research. https://doi.org/10.1093/hcr/30.3.411

Marston, C. L., \& Shrives, P. J. (1991). The use of disclosure indices in accounting research: A review article. In The British Accounting Review. https://doi.org/10.1016/08908389(91)90080-L

Memed sueb, \& Keraf, M. N. I. (2012). Jurnal Dinamika Manajemen. 3(1), 69-75.

Milne, M. J., \& Adler, R. W. (1999). Exploring the reliability of social and environmental disclosures content analysis. Accounting, Auditing \& Accountability Journal, 12(2), 237256. https://doi.org/10.1108/09513579910270138

Patten, D. M. (1992). Intra-industry environmental disclosures in response to the Alaskan oil spill: A note on legitimacy theory. Accounting, Organizations and Society. https://doi.org/10.1016/0361-3682(92)90042-Q

Profile, S. E. E. (2019). SEMIOTIK. January.

Purwanto, A. T. (1998). Manajemen Lingkungan: Dulu, Sekarang, dan Masa Depan. Manajemen Lingkungan, 04, 1-28.

Pusat, Makro, E., Fiskal, B. K., \& Keuangan, D. (2009). Stabilitas Sistem Keuangan dan Pertumbuhan Ekonomi yang Rerkelanjutan dalam Rangka Mewujudkan Negara Kesejahteraan. Kajian Ekonomi Dan Keuangan, 13.

Rajafi, L. R., \& Irianto, G. (2007). ANALISIS PEN GUN GKAPAN LAPORAN SOSIAL DAN LINGKUNGAN SEBAGAI BAGIAN DARI TRIPLE BOTTOM LINE REPORTING DAL AM AKUNTANSI PERTANGGUNGJAWABAN SOSIAL PERUSAHAAN: Studi Perbandingan Rata- Rata Tema Pengungkapan Antar Kelompok Industri yang Terdaftar pada Bursa. Tema, 8(1), 72-91. https://s3.amazonaws.com/academia.edu.documents/31300863/97.pdf?response-contentdisposition=inline $\% 3 \mathrm{~B}$

filename\%3DAnalisis_Pengungkapan_Laporan_Sosial_dan.pdf\&X-AmzAlgorithm=AWS4-HMAC-SHA256\&X-Amz-

Credential=AKIAIWOWYYGZ2Y53UL3A\%2F20190617\%2Fus-east-1\%2F

Visser, W., \& Elkington, J. (2013). Cannibals with Forks. The Top 50 Sustainability Books, April, 108-112. https://doi.org/10.9774/gleaf.978-1-907643-44-6_24 
Journal Accounting and Finance

Edisi Vol. 5, No. 2, September 2021

Universitas Telkom

Wiseman, J. (1982). An evaluation of environmental disclosures made in corporate annual reports. Accounting, Organizations and Society, 7(1), 53-63. https://doi.org/10.1016/0361-3682(82)90025-3 